\title{
Nevoid basal cell carcinoma syndrome (Gorlin syndrome)
} Lorenzo Lo Muzio

\author{
Address: Dipartimento di Scienze Chirurgiche, Facoltà di Medicina e Chirurgia, Università degli Studi di Foggia, Foggia, Italy \\ Email: Lorenzo Lo Muzio - llomuzio@tin.it
}

Published: 25 November 2008

Received: 18 February 2008

Orphanet Journal of Rare Diseases 2008, 3:32 doi:10.1 I86/I750-I I72-3-32

Accepted: 25 November 2008

This article is available from: http://www.ojrd.com/content/3/I/32

(C) 2008 Lo Muzio; licensee BioMed Central Ltd.

This is an Open Access article distributed under the terms of the Creative Commons Attribution License (http://creativecommons.org/licenses/by/2.0), which permits unrestricted use, distribution, and reproduction in any medium, provided the original work is properly cited.

\begin{abstract}
Nevoid basal cell carcinoma syndrome (NBCCS), also known as Gorlin syndrome, is a hereditary condition characterized by a wide range of developmental abnormalities and a predisposition to neoplasms.

The estimated prevalence varies from I/57,000 to I/256,000, with a male-to-female ratio of I:I.

Main clinical manifestations include multiple basal cell carcinomas (BCCs), odontogenic keratocysts of the jaws, hyperkeratosis of palms and soles, skeletal abnormalities, intracranial ectopic calcifications, and facial dysmorphism (macrocephaly, cleft lip/palate and severe eye anomalies). Intellectual deficit is present in up to $5 \%$ of cases. BCCs (varying clinically from flesh-colored papules to ulcerating plaques and in diameter from I to $10 \mathrm{~mm}$ ) are most commonly located on the face, back and chest. The number of BBCs varies from a few to several thousand. Recurrent jaw cysts occur in $90 \%$ of patients. Skeletal abnormalities (affecting the shape of the ribs, vertebral column bones, and the skull) are frequent. Ocular, genitourinary and cardiovascular disorders may occur. About 5-10\% of NBCCS patients develop the brain malignancy medulloblastoma, which may be a potential cause of early death.
\end{abstract}

NBCCS is caused by mutations in the PTCHI gene and is transmitted as an autosomal dominant trait with complete penetrance and variable expressivity.

Clinical diagnosis relies on specific criteria. Gene mutation analysis confirms the diagnosis. Genetic counseling is mandatory. Antenatal diagnosis is feasible by means of ultrasound scans and analysis of DNA extracted from fetal cells (obtained by amniocentesis or chorionic villus sampling). Main differential diagnoses include Bazex syndrome, trichoepithelioma papulosum multiplex and Torre's syndrome (Muir-Torre's syndrome).

Management requires a multidisciplinary approach. Keratocysts are treated by surgical removal. Surgery for BBCs is indicated when the number of lesions is limited; other treatments include laser ablation, photodynamic therapy and topical chemotherapy. Radiotherapy should be avoided. Vitamin A analogs may play a preventive role against development of new BCCs.

Life expectancy in NBCCS is not significantly altered but morbidity from complications can be substantial. Regular follow-up by a multi-specialist team (dermatologist, neurologist and odontologist) should be offered. Patients with NBCCS should strictly avoid an excessive sun exposure. 


\section{Disease name and synonyms}

Nevoid basal cell carcinoma syndrome (NBCCS)

Gorlin syndrome

Gorlin-Goltz syndrome

Basal cell nevus syndrome, BCNS (OMIM 109400)

Fifth phacomatosis

\section{Definition}

The syndrome, delineated by Gorlin and Goltz in 1960 [1], was first reported in $1894[2,3]$ and has been given several different names:

- Gorlin syndrome

- Gorlin-Goltz syndrome

- Nevoid basal cell carcinoma syndrome (NBCCS)

- Multiple nevoid basal-cell carcinoma syndrome (MNBCCS)

- Multiple basal-cell carcinoma syndrome

- Basal cell nevus syndrome (BCNS)

- Multiple basalioma syndrome

- Fifth phacomatosis

- Jaw cysts-basal cell tumors-skeletal anomalies syndrome

- Odontogenic keratocytosis-skeletal anomalies syndrome

- Multiple nevoid basal-cell epithelioma-jaw cysts-bifid rib syndrome

- Hereditary cutaneomandibular polyoncosis

- Epitheliomatose multiple generalisee

Currently, this disorder, resulting from mutations in the PTCH1 gene, is called the nevoid basal cell carcinoma syndrome (NBCCS), as Professor Gorlin suggested. However, patients and their relatives prefer to use the name "Gorlin syndrome", since it does not contain the word "carcinoma", even if about $50 \%$ of white patients will develop a significant number of skin cancers. Skin cancers do not generally occur in black patients [4].
Diagnostic criteria, based on the most frequent and/or specific features of the syndrome, were defined by Evans et al. in the Journal of Medical Genetics in 1993 [5], and modified by Kimonis et al. in 1997 [6].

\section{Epidemiology}

This syndrome existed during Dynastic Egyptian times as shown by a constellation of findings compatible with the syndrome in mummies dating back to 1,000 b.c. [7]. In 1992, Farndon et al. estimated that the minimum prevalence is 1 per $57,000[8,9]$. An almost identical value was noted by Pratt and Jackson [10]. A study in the North West of England showed that the disease affects 1 in 55,600 people [5]. In Italy, the incidence $(1 / 256,000)$ [11] of the disease appears to be lower than in Australia $(1 / 164,000)$ [12] and in the United Kingdom [5] (Table 1). Rahbari and Mehregan noted that $2 \%$ of patients under 45 years of age with basal cell carcinomas have the syndrome [13]. Recently two new studies reported the incidence of the syndrome in Korea [14], and in France[15].

\section{Clinical description}

Many different signs and symptoms may be associated with NBCCS (Table 2). Clinical manifestations include basal cell carcinomas (BCCs), which may appear very early (2 years of age) [16]; odontogenic keratocysts (OKCs) that generally develop in the first, second and third decades $[6,11,12,17,18]$; palmar and/or plantar pits, and ectopic calcifications of the falx cerebri. These manifestations are considered as the major criteria for diagnosis [5]. The disorder is also characterized by congenital skeletal abnormalities, macrocephaly with frontal bossing, cleft lip and/or palate, and eye anomalies. Various low-frequency neoplasms, such as medulloblastomas, meningiomas, and ovarian and cardiac fibromas have been also reported (Table 2).

\section{Skin}

Basal cell carcinomas may arise in various stages of the syndrome: most often they appear between puberty and 35 years of age [16], but cases have been reported in 3 or 4 year-old patients [5,12]; in general, the mean age of onset is about 25 years of age. The incidence varies widely among ethnic groups: only about $40 \%$ of black patients affected by NBCCS manifest BCCs, while in whites they are reported in up to $90 \%$ of cases. However, the incidence in whites is also variable with some studies showing a lower prevalence (30\%), probably due to protective skin pigmentation [11], as already established for AfricanAmerican patients $[6,19]$. BCCs may vary in number (from a few to literally thousands) and range in size from 1 to $10 \mathrm{~mm}$ in diameter. Clinically, they may vary from flesh-colored papules to ulcerating plaques and may be mistaken for skin tags, nevi, or hemangiomas. There appears to be a relationship with increased sun exposure, 
Table I: Comparison of prevalence and frequency of major criteria in NBCCS patients among four studies.

\begin{tabular}{|c|c|c|c|c|c|c|}
\hline & $\begin{array}{l}\text { Evans et al. [5] } \\
\text { United Kingdom, } \\
\text { I993 }\end{array}$ & $\begin{array}{l}\text { Shanley et al. [12] } \\
\text { Australia, } 1994\end{array}$ & $\begin{array}{l}\text { Kimonis et al. [6] } \\
\text { United States, } \\
\text { I997 }\end{array}$ & $\begin{array}{l}\text { Lo Muzio et al. } \\
\text { [II] Italy, } 1999\end{array}$ & $\begin{array}{l}\text { Ahn SG et al. [14] } \\
\text { Korea, } 2004\end{array}$ & $\begin{array}{l}\text { Pruvost-Balland et } \\
\text { al. [15] France, } \\
2006\end{array}$ \\
\hline Patients & 84 & 118 & 105 & 37 & 33 & 22 \\
\hline Prevalence & $1 / 56,000$ & $1 / 164,000$ & NR & $1 / 256,000$ & $1 / 13,939,393$ & NR \\
\hline \multicolumn{7}{|c|}{ Major criteria \% or (\% African-Americans) } \\
\hline $\mathrm{BCCs}$ & 47 & 76 & $80(38)$ & 30 & 15.2 & 100 \\
\hline Age $>20 y$ & 73 & 85 & 91 & 17 & - & - \\
\hline Age $>40 y$ & 90 & 95 & 97 & 75 & - & - \\
\hline Jaw cyst & 66 & 75 & 74 & 92 & 90.9 & 62 \\
\hline Palm/plant pits & 71 & 80 & 87 & 35 & 66.7 & 45 \\
\hline $\begin{array}{l}\text { Calcification of falx } \\
\text { cerebri }\end{array}$ & NR & 92 & 65 & 70 & 21.2 & 66 \\
\hline
\end{tabular}

NBCCS $=$ Nevoid basal cell carcinoma syndrome; NR-Non reported

and therefore BCCs are most likely to appear on the sunexposed parts of the body, but non-exposed areas may also be involved. The most common locations are the face, the back, and the chest; the waist and extremities are rarely involved; BCCs have also been described on genitalia [20]. BCCs in this syndrome behave in the same manner as sporadic BCCs. In general, it is after puberty that the basal cell cancers become aggressive and invade locally [5]. If a lesion increases in size or begins to bleed or crust, invasion should be suspected and excluded. Radiation therapy must be avoided $[6,21]$, since tumors may appear in the radiation fields even after many years [16]. Evidence of metastatization has been rarely reported $[22,23]$. If left untreated, BCCs can lead to disfigurment, especially on the face. Wang and Goldberg reported a patient with NBCCS who developed multiple polypoid basal cell carcinomas (PBCC) in the perineum, leading to the recommendation that the perineum, perianal, and genital areas should be included in the routine examination of patients with NBCCS [24]. The histopathology of nevoid BCC cannot be differentiated from that of ordinary sporadic BCC [4]. The tumors are composed of nests and islands or sheets of large, deeply-stained nuclei with indistinct cell membranes [4]. At the periphery of each lesion, the epithelial cells are well-polarized, suggestive of cutaneous basal cells. About $30 \%$ of NBCCS patients have two or more types of BCC patterns (morphea-like, solid, superficial, cystic, adenoid, fibroepithelial) [4]. Commonly (30-50\% of cases), there are milia intermixed with the basal cell islands and calcified foci may be noted, not only within the tumor but also in normal skin [4]. Perhaps this reflects the "turning on" of the bone morphogenetic protein $(B M P)$ gene [4].
Between $30 \%$ and $65 \%$ of patients with the syndrome have small asymmetric palmar-plantar pits by the age of 10 years, this percentage rising to $80 \%$ by the age of 15 $[21,25]$. Pits occur in $85 \%$ of patients over the age of 20 years [25]. These lesions are $2-3 \mathrm{~mm}$ in diameter and 1$3 \mathrm{~mm}$ in depth [26], with the color of the base being red in caucasians and black in africans. They increase in number with age, are permanent, and are a strong diagnostic indicator whenever found in a child. They are found more commonly on the palms $(77 \%)$ than on the soles $(50 \%)$. The pits may be easier to see if the hands are soaked in warm water for about 10 minutes. No BCC has been found to arise from these pits [21].

Multiple nevi are present in $30-50 \%$ of patients under 20 years of age, rising to $70 \%$ in patients over the age of 20 years. The nevi are flesh colored, reddish brown or pearly, and the groups resemble moles, skin tags, an ordinary nevus, cell nevi or hemangiomas. Some of them grow rapidly for a few days (to a few weeks), then mostly remain static.

Other skin signs are nodular or patch lesions, and benign dermal cysts. Small keratin-filled cysts ( milia) can be found on the face in $30 \%$ of cases, most commonly in the area below the eyes, but they can also occur on the forehead.

Epidermoid cysts occur on the limbs and the trunk in over $50 \%$ of cases. They are usually $1-2 \mathrm{~cm}$ in diameter and are particularly common around the knee. Skin tags are especially common around the neck; histopathology reveals the typical features of a basal cell carcinoma, but the skin tags do not generally change in size or shape. 
Table 2: Disorders reported in patients with basal cell nevus syndrome.

Skin
Cutaneous dyskeratosis:
$\circ$ erythematous-squamous spots degenerating in NBCC
$\circ$ nodular or patch lesions
$\circ$ palmo-plantar pits
Multiple basal cell carcinomas
Benign dermal cysts
$\circ$ Multiple nevi

Clinical manifestations

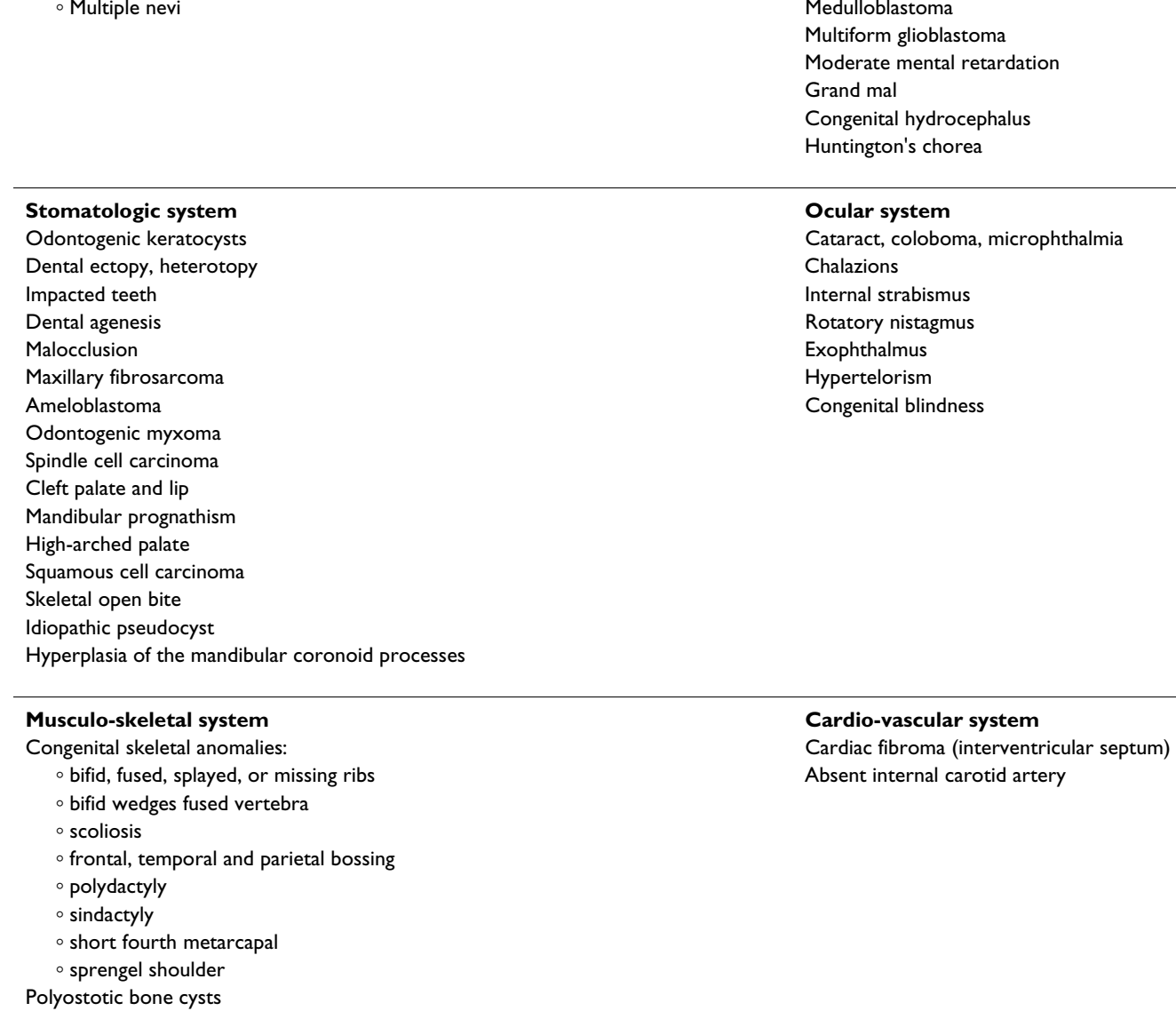

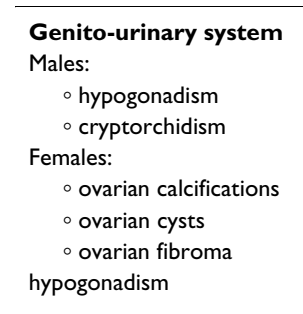

\section{Respiratory system}

Bronchogenic cysts

Hyaline membrane disease

\author{
Central nervous system \\ Ectopic calcification: \\ - falx cerebri \\ - tentorium cerebelli \\ - spotted meningeal calcification \\ - complete or partial bony bridging of the sella turcica
}

Meningioma

Medulloblastoma

Multiform glioblastom

Grand mal

Congenital hydrocephalus

Ocular system

Chalazions

Rotatory nistagmus

Cardio-vascular system

Cardiac fibroma (interventricular septum)

Absent internal carotid artery

Gastro-enteric system

Linfomesenteryc cysts

Gastric polyps 
Recently, Wilson et al. reported the occurrence of hairy skin patches (discrete patches of unusually long pigmented hair) on the skin of three patients affected by Gorlin syndrome from two unrelated families with confirmed heterozygous mutations in the PTCH1 gene, suggesting that the patches may represent a sign associated with the syndrome [27].

\section{Stomatologic system}

Recurrent jaw cysts are the main oral sign, being present in $90 \%$ of patients [11]. These cysts are known as keratocysts as they are characterized by a thin external fibrous capsule and an internal lining of keratinized stratified squamous epithelium. Keratocysts appear in the toothbearing areas of the jaws, and are believed to arise from the dental lamina [21]. Cysts may appear in both jaws. In several cases, the first symptom is either an odontogenic keratocyst or an odontogenic cyst of the jaws $[11,18]$. Odontogenic keratocysts (OKCs) are the most consistent and representative signs of NBCCS in the first and the second decades of life. OKCs are detected in patients under 10 years of age $[5,12]: 13 \%$ of patients develop a jaw cyst by the age of 10 years and $51 \%$ by the age of 20 years. These data suggest that lesions may start to develop as early as at 7 or 8 years of age and underline the fact that keratocysts in patients affected by NBCCS arise earlier than those in healthy subjects $[28,29]$. In NBCC patients, there is continued development of new and recurring cysts until about age 30, when the rate of development tends to decrease [30]. Most non-NBCCS keratocysts are isolated lesions, but in NBCCS the keratocysts are commonly multiple, from 1 to 30 , and the average number is 5 . The most common site in the mandible is the molar-ramus region (44\%), followed by the incisor-canine region (18\%) [18]. In contrast, the majority of maxillary cysts occur in the incisor-canine (15\%) and molar-tuberosity (13\%) regions [18]. Only a few cysts have been reported in the premolar region. There is no racial predilection. There may be remarkably few symptoms until cysts reach a large size, especially when the ascending ramus is involved. Presentations include swelling and/or displaced, impacted teeth. About one-half of patients present with swelling, a quarter with mild pain, and $15 \%$ with an unusual taste following rupture of a cyst. Despite these manifestations, jaw fractures almost never occur. Radiographically, the keratocyst may show a unilocular or multilocular pattern and the cystic spaces may have a smooth or scalloped border. One of the most problematic aspects is the $60 \%$ rate of recurrence following surgery. In part, this may be due to incomplete removal, i.e., from retention of epithelial islands and/or satellite microcysts, which occur with great frequency in the connective tissue capsule, or from proliferation of the basal layer of the epithelium [31]. There have been a few reports of ameloblastoma arising in odontogenic keratocysts [32] or, rarely, of squamous cell carci- noma [33]. Microscopically, the odontogenic keratocysts are multilocular with a parakeratinized $(96 \%)$ or, rarely, orthokeratinized (4\%) stratified squamous epithelium consisting of only a few layers of cells (about five to eight) with a well-defined basal epithelial cell layer, palisaded nuclei but no rete ridges [4]. Budding of the epithelium into the connective tissue with suprabasilar splitting has been noted in at least $50 \%$ of cases [4].

Other defects of the stomatologic system are malocclusion, impacted teeth, mandibular prognathism, dental ectopy or heterotopy, and dental agenesis. Cleft palate and lip are rare $(5 \%)[34,35]$. Recently, a new sign has been described: bilateral hyperplasia of the mandibular coronoid processes [36], which may be a radiologic criterion for the syndrome, useful for establishing a diagnosis especially in pediatric patients [37].

\section{Ectopic calcification of the central nervous system and other brain signs}

Ectopic calcifications of the central nervous system have been reported: lamellar calcification of the falx cerebri (7085\%) [11], calcification of the tentorium cerebelli (20-40\%) [11], the petroclinoid ligament (20\%) and the diaphragma sellae $(60-80 \%)$ [38], and complete or partial bony bridging of the sella turcica (25\%) [11]. Spotted meningeal calcifications are rare. These signs may not result in clinical manifestations, but can be useful in confirming the diagnosis. The calcification of the falx cerebri can appear very early in life, and is often strikingly apparent from late childhood. Other signs reported are cysts of the choroid plexus of the third and lateral ventricles of the brain, intraparenchymal brain cysts, arachnoid cysts, glial nodules projecting from the lateral ventricles, agenesis of the corpus callosum with or without lipoma [39], "empty" sella syndrome [39], communicating hydrocephalus [40-43], meningioma $[44,45]$, cysts of the septum pellucidum [46] and medulloblastoma [44,47-55] (see the paragraph "Other tumors"). Vermian dysgenesis has been noted in a mother and a daughter $[56,57]$. Seizures have occasionally been noted unassociated with brain tumors and possibly due to focal neuronal heterotopia [58]. Mental retardation occurs in about $5 \%$ of cases.

\section{Skeletal system}

Skeletal manifestations are also present in NBCCS [46]. The signs in the bones found on X-ray may be helpful in making the diagnosis. The height (these patients can be much taller than expected for their family), the shape of the ribs, the shape of the bones in the vertebral column, and the shape of the skull are principally affected $[46,59]$. Mean height is increased $(183 \mathrm{~cm}$ in males, $174 \mathrm{~cm}$ in females) and about $15 \%$ of patients are extremely tall [4]. An abnormal skull configuration (characterized by frontal (25\%), biparetial or temporal bossing, and large calvaria) 
is frequent (70\%) [11]. Relative macrocephaly with an occipital frontal circumference above the $95^{\text {th }}$ centile has been reported in $50 \%$ of cases $[6,59]$. As a result of the abnormal growth of the skull (>60 cm in adults), about $70 \%$ of patients affected by NBCCS have eyes which appear wider apart than usual. Other skeletal signs are scoliosis $(40 \%)$, and abnormalities such as bifid, wide, fused, partially missing or underdeveloped ribs (30-60\%) [11]. Rib abnormalities may give rise to a prominent or depressed sternum in about $30 \%-40 \%$ of patients. Spina bifida occulta of the cervical or thoracic vertebrae is found in $60 \%$ of cases [60]. However, in a series studied by Kimonis et al., the spina bifida occulta occurred in only $20 \%$ of patients [6]. Bifid wedges, fused vertebra and Sprengel anomaly (elevation of the scapula with rotation toward the spine with scoliosis) are observed in 10 to $40 \%$ of patients. Extra digits on the hands or feet can occur. In about $35 \%$ of individuals with Gorlin syndrome, an X-ray of the hands will show small cysts in the bones of the fingers. The numbers and site can be very variable. Bone cysts can also occur in the long bones of the arms and legs, the pelvis and the calvaria [61]; usually, these do not cause problems, even if calvarial involvement may give the erroneous impression that medulloblastoma has spread to bone [62]. Histologically, the flame-like lesions consist of fibrous connective tissue, nerves, and blood vessels, i.e., they are hamartomas [4].

\section{Ocular system}

NBCCS patients may have various ocular problems that occur with a frequency higher than that in the normal population (20\%). These include hypertelorism (70\%), exophthalmus, rotatory nystagmus, internal strabismus, congenital cataracts, orbital cysts, coloboma of the iris, choroid, and optic nerve, microphthalmia, and chalazions $[5,11,21,63]$. Most striking are small very transient keratin-filled cysts (milia) found on the palpebral conjunctivae in about $40 \%$ of cases [4]. This observation is a personal one, reported by a parental support group in Manchester, England [4]. The author asked the assembled group if they had ever had one or more of these transient cysts [4], and this exercise was repeated for the American support group for NBCCS [4]. Due to the transient nature of these cysts, most of the patients noted that they were not significantly disturbed by their presence, but they had been to ophthalmologists who confirmed the presence of milia of the palpebral mucosa [4].

\section{Genito-urinary system}

Ovarian cysts and fibromas are present in $25-50 \%$ of affected women [5] and are often bilateral (75\%). Ovarian calcifications are reported and may be mistaken for calcified uterine fibroids or calcified uterine leiomyomas. They do not seem to reduce fertility but may undergo torsion (twist). Some cases of ovarian fibrosarcoma [64] and primary ovarian leiomyosarcoma [65] have been reported. Males may exhibit hypogonadotrophic hypogonadism (5-10\%), cryptorchidism, female pubic escutcheon, or gynecomastia. Other signs involving the kidneys (5\%) may be: horseshoe kidney, L-shaped kidney, unilateral renal agenesis, renal cysts, or duplication of the renal pelvis and ureter.

\section{Mesenteric cysts}

Single or multiple chylous or lymphatic mesenteric cysts have been documented [4,66-68]. The cysts are thinwalled and measure 2 to $14 \mathrm{~cm}$ in diameter, do not produce symptoms, and are often an occasional finding [21]. The content is chylous but may contain hemorrhagic turbid fluid [4]. Microscopically, the wall is composed of fibrous connective tissue and smooth muscle, and a layer of lymphatic cells is often located beneath the endothelial lining [4].

\section{Cardiovascular system}

Fibroma of the heart has been described $[5,21,46,69-74]$. The syndrome is present in 3-5\% of all patients with a cardiac fibroma $[5,69]$. The cardiac fibroma is discrete, wellcircumscribed, not encapsulated, firm, gray-white, 3 to 4 $\mathrm{cm}$ in diameter, and may, upon occasion, exhibit central calcification [4]. The tumor is most often located in the left anterior ventricular wall. If the tumor projects into the chambers, hemodynamics is altered and/or impeded. Conduction defects (i.e., arrhythmias) may also be present due to involvement of the intraventricular septum [75]. The tumors are composed of fibroblasts embedded in a dense matrix of collagen and elastic fibers.

\section{Other tumors}

Tumors in patients with NBCCS include basal cell carcinoma, medulloblastoma, fibroma and rhabdomyosarcoma (RMS) [76-78]. RMSs are also present in $15 \%$ of mice haplodeficient for PTCH1 [79]. Medulloblastoma is frequent [44,47-55]; Herzberg and Wiskemann first pointed out the association of NBCCS with medulloblastoma in 1963 [80]. The tumor characteristically presents during the first two years of life, while in the general population occurrence peaks at 7 to 8 years of age. The incidence of medulloblastoma in Evans' series was 1\% to 2\% [5]. There is a sex predilection with a male-to-female ratio of 3:1. Early onset medulloblastoma may be the presenting sign of NBCCS; thus, in children in which this tumor is diagnosed, NBCCS should be suspected and a careful examination for other signs of the syndrome should be performed in order to rule it out [6]. There is some evidence that medulloblastomas associated with NBCCS have a better clinical outcome than those found in isolation $[47,81,82]$, with the possibility of spontaneous recovery [82]. Radiation therapy for medulloblastoma can 
induce invasive BCCs in the radiation field (i.e., from the nape to base of the spine) [83].

Other brain tumors, such as astrocystoma, craniopharyngioma, and oligodendroglioma, are infrequent, while meningioma is slightly more common. These tumors may well be secondary to radiation therapy.

In 1968, Schweisguth et al. reported fetal rhabdomyoma [84]. This tumor has been described at various sites $[21,78,85-89]$. Mature striated muscle within the tumor is indicative for diagnosis.

There are several reports that support an increased incidence of other neoplasms or hamartomas, such as leiomyomas of bowel and mesentery, leiomyosarcoma, adrenal cystic lymphangioma, thyroid adenoma, lymphangiomyoma, melanoma, ameloblastoma, craniopharyngioma, mesenchymoma, Hodgkin's lymphoma, non-Hodgkin's lymphoma, seminoma, paratesticular pseudotumor, schwannoma, pleiomorphic adenoma of parotid, adenoid cystic carcinoma of salivary gland, and adrenal tumors [90-92].

\section{Etiology}

NBCCS is a hereditary condition caused by mutations in the PTCH1 gene and is transmitted in an autosomal dominant manner with high penetrance and variable expressivity $[93,94]$. There is no sexual predilection. Individuals with no known affected family members may comprise up to $60 \%$ of all affected individuals [95].

The PTCH1 gene has recently been mapped to the long arm of chromosome 9 (q22.3-q31) with no apparent heterogeneity $[8,96]$. Approximately $50 \%$ of NBCCS patients have allelic losses including this site [97]. Data suggest that the product of this gene acts as a tumor suppressor $[96,98,99]$. Furthermore, the typical malformative pattern of NBCCS suggests that the gene has a fundamental function in controlling growth and development of normal tissues [100]. This gene was isolated in 1996 as the human homolog of the Drosophila PTCH1 gene, simultaneously in Australia and in the USA [101,102].

The PTCH1 gene in the fruit fly is important for body segmentation. If the gene is faulty, abnormal segmentation occurs. Several mutations of the PTCH1 gene have been identified in patients with NBCCS [101-118], and, in those with BCCs and medulloblastomas that are apparently not hereditary $[119,120]$.

The gene consists of 23 exons, which span $34 \mathrm{~kb}$. It encodes a transmembrane glycoprotein composed of 1447 amino acids, with 12 transmembrane domains and two large hydrophilic extracellular loops where Sonic
Hedgehog (SHH) ligand binding occurs. If a mutation occurs in PTCH1 and the second loop is not formed, $\mathrm{SHH}$ cannot bind.

Thus, the PTCH1 gene product acts as membrane receptor [121] for the SHH signal and represses transcription (in certain cells) of genes encoding signaling proteins belonging to the transforming growth factor (TGF)-beta and Wnt families. The Hedgehog (Hh) family comprises several regulation factors described in several species. SHH is a true signaling switch used in differentiating subpopulations of cells throughout the embryo; in fact, SHH patterning is involved in several embryonal processes, such as the formation of the ventral neural tube (basal plate, motor columns), the limb bud, parts of the brain, hair follicle development, and tooth development. PTCH1 in the absence of its ligand, $\mathrm{SHH}$, acts a cell-cycle regulator, normally inhibiting expression of downstream genes that control cell fate, patterning, and growth [122]. In the case of a C-terminal truncation caused by a mutation in $P T C H 1$, these genes are no longer repressed.

The molecular biology of cancers in NBCCS is similar to that of retinoblastoma, the prototypical pediatric cancer syndrome, which is characterized by mutations in a recessive oncogene. Data from patients with retinoblastoma support the Knudson two-hit hypothesis; this theory of oncogenesis states that normal cells require two mutagenic hits (two distinct episodes of DNA damage) to produce a cancer. Patients with retinoblastoma, NBCCS, and other similar syndromes have a constitutional (germline) defect in the DNA sequence in one of the two copies of a tumor suppressor gene. A defect in one of the two copies is insufficient to cause a cancer. If a second DNA injury or if loss of the normal remaining allele occurs at the same locus (the second hit), the cell may become malignant. In NBCCS, various tumors and hamartomas (BCC, OKCs, meningiomas, ovarian fibromas) exhibit loss of heterozygosity $[123,124]$, but other lesions do not, for example, palmar pits [125]. Loss of heterozygosity at the PTCH1 locus has been observed in almost $90 \%$ of hereditary BCCs. Various physical anomalies (bifid rib, macrocephaly) apparently need only one hit. An interesting aspect of this syndrome is that some of the developmental defects (e.g. jaw cysts) appear to have two genetic hits but without developing into a true malignancy. In some patients, the lining of these odontogenic keratocysts has lost the normal gene for NBCCS, while retaining the mutant allele. Agaram et al. found that $70 \%$ of jaw cysts showed loss of heterozygosity of one or more of the several common tumor suppressor genes [126]. This finding may explain the behavior of jaw cysts, which may be more similar to low-grade neoplasms than congenital malformations. 
Analysis of gene mutations in the syndrome has identified deletions, insertions, splice site alterations, nonsense and missense mutations, with no hot spots identified for mutations. About $70 \%$ of germ-line PTCH1 mutations are rearrangements. Over $80 \%$ of these mutations seem to result in a truncation of the coded protein [115], which suggests that developmental anomalies seen in NBCC syndrome may be due to haplo-insufficiency [127]; recently, PTCH1 mutations have been reported as a result of errors in the recombinational repair process [109].

In 2006 Lindström et al. analyzed 284 mutations and 48 single nucleotide polymorphisms (SNPs) located in the PTCH1 gene, compiled from a PTCH1 mutation database [110]. They found that the PTCH1 mutations were mainly clustered into the two large extracellular loops of the corresponding protein and its large intracellular loop [110]. The SNPs appeared to be clustered around the sterol-sensing domain and the second half of the protein [110]. NBCCS cases and each class of tumor analyzed revealed a different distribution of the mutations in the various PTCH1 domains [110]. Moreover, the types of mutations were also unique for the different groups [110]. Finally, the PTCH1 gene harbors mutational hot spot residues and regions, including a slippage-sensitive sequence in the $\mathrm{N}$ terminus [110].

Several studies reported polymorphisms for the PTCH1 gene in North American [128], European [115,129], Chinese [130], and Japanese [131] populations. Some of these polymorphic variants (i.e., $1686 \mathrm{C}>\mathrm{T}, 2199 \mathrm{~A}>\mathrm{G}$, 3944T>C, IVS10-51G>C, IVS10-8T>C) occur with a high frequency. A recent study has reported that certain haplotypes of PTCH1 polymorphisms may mediate the susceptibility to basal cell carcinomas [132]. Pedigrees with multiple features of NBCCS were most likely to test positive for PTCH1 mutations [133]. Pedigrees with multiple or early-onset basal cell carcinomas without other features of the disease did not test positive for PTCH1 mutations [133].

PTCH2, highly homologous to PTCH1, has been mapped to chromosome 1p32.1-p32.3 [134]. PTCH2 comprises 22 coding exons and spans approximately $15 \mathrm{~kb}$ [134]. It encodes a 1203 amino acid putative transmembrane protein that is highly homologous to the PTCH1 product. Mutations have been found in one simplex case (i.e., a single occurrence of the disease in a family) of medulloblastoma and one simplex case of BCC [134]. No PTCH2 mutations were found in 11 simplex cases of NBCCS or in 11 individuals with familial cases of NBCCS who did not have identifiable PTCH1 mutations. In many cases, medulloblastoma arising from perturbations of PTCH1 function leads to a concomitant up-regulation of the highly similar gene PTCH2. Lee et al. investigated the role of PTCH2 in tumor suppression by generating PTCH2deficient mice [135]. In striking contrast to PTCH1-/mice, PTCH2-/- animals were born alive and showed no obvious defects and were not cancer prone [135]. However, loss of PTCH 2 markedly affected tumor formation in combination with PTCH1 haploinsufficiency. PTCH1+/PTCH2-/- and PTCH1+/-PTCH2+/- animals showed a higher incidence of tumors and a broader spectrum of tumor types compared with PTCH1+/- animals [135]. Therefore, PTCH 2 modulates tumorigenesis associated with PTCH1 haploinsufficiency [135].

\section{Diagnostic methods}

Diagnosis of NBCCS can be made in the presence of two major criteria or one major and two minor criteria [6]:

\section{Major criteria}

1. Multiple (>2) BCCs or one under 20 years

2. Odontogenic keratocysts of the jaws proven by histopathology

3. Palmar or plantar pits (3 or more)

4. Bilamellar calcification of the falx cerebri

5. Bifid, fused or markedly splayed ribs

6. First degree relatives with NBCCS

\section{Minor criteria}

1. Macrocephaly determined after adjustment for height

2. Congenital malformation: cleft lip or palate, frontal bossing, "coarse face", moderate of severe hypertelorism

3. Other skeletal abnormalities: sprengel deformity, marked pectus deformity, marked syndactyly of the digits

4. Radiological abnormalities: bridging of the sella turcica, vertebral anomalies such as hemivertebrae, fusion or elongation of the vertebral bodies, modeling defects of the hands and feet, or flame-shaped lucencies of the hands or feet

\section{Ovarian fibroma}

\section{Medulloblastoma.}

The presence of the most frequent and/or specific features of the syndrome make the diagnosis easier; however, diagnosis in a child with a $50 \%$ risk of having inherited the condition may not be so easy because of the extreme variation in expression, both within and between families. Some children may have only rib anomalies, whilst others 
have the "typical face" without other signs. Gene tracking and mutation analysis may be helpful for pre-symptomatic diagnosis.

For apparently isolated cases, detailed examination and Xray investigation of the relatives should be undertaken before concluding that a child's condition is the result of a new mutation. If an adult has no sign, no pertinent history and normal radiology, it is unlikely that he or she has Gorlin syndrome. Direct mutation analysis of the gene may be helpful. It is particularly helpful to follow a specific clinical protocol in the examination of these subjects (Table 3).

In case of a family history of the disease, at birth or immediately after, a detailed examination should look for the presence of a large head, frontal and temporal bossing, cleft palate [35], eye anomalies and bifid ribs $[16,19]$, or vertebral anomalies. In order to detect a deficit related to a medulloblastoma, a neurological examination is recommended every six months [5]. At 3 years, the frequency of examinations could be reduced to once a year until 7 years of age, after which a medulloblastoma is very unlikely.

A panoramic radiograph of the jaws once a year from the age of 8 years onward is also suggested [18]. The appearance of two or more recidivant OKCs, or an early OKC in a young subject, is suggestive of NBCCS syndrome. An at least annual examination of the skin from puberty is recommended but as a lesion may suddenly become aggressive, the patient needs open access to the specialist taking responsibility for treatment of the skin.

Table 3: Diagnostic protocols in NBCCS.

\begin{tabular}{l}
\hline Family history \\
$\circ$ past medical and dental history \\
Clinical examinations \\
$\circ$ oral \\
$\circ$ skin \\
$\circ$ central nervous system \\
$\circ$ head circumference \\
$\circ$ interpupillar distance \\
$\circ$ eyes \\
$\circ$ genito-urinary system \\
$\circ$ cardio-vascular system \\
$\circ$ respiratory system \\
$\circ$ skeletal system \\
Genetic testing \\
X-ray \\
$\circ$ chest \\
$\circ$ A.P. and lateral skull \\
$\circ$ Panoramic radiograph \\
$\circ$ Cervical and thoracic spine - A.P. and lateral \\
$\circ$ Hands (for pseudocysts) \\
$\circ$ Pelvic (female) \\
Ovarian ultrasound (female) for ovarian fibroma \\
Echocardiogram (children) for cardiac fibroma \\
\hline
\end{tabular}

In children at risk, diagnosis can often be achieved by radiographic means (calcification of falx, rib anomalies, calcification of ovarian fibromas). Depending on the situation, imaging studies may include magnetic resonance imaging (MRI) of the brain, echocardiography, abdominal ultrasonography, dental radiography, and skeletal survey. Kimonis et al. described the radiologic findings that are most helpful in diagnosing NBCCS [46]. As patients with NBCCS are especially sensitive to ionizing radiation, the use of irradiation should be minimized when possible. Nevertheless, definitive presymptomatic diagnosis can be achieved by molecular genetic linkage. Rarely, babies can have fibromas in the heart: at least two cases have presented before 3 months of age with fibromas $[71,136]$.

No specific laboratory studies are indicated; however, several laboratories offer commercial testing for Gorlin syndrome and testing is certainly indicated in children with desmoplastic medulloblastoma, where radiation is contemplated. Patients with suspected Gorlin syndrome should undergo biopsy with samples obtained from several suspicious skin lesions. The histologic features of BCCs in Gorlin syndrome are usually identical to those observed in sporadic BCCs. Medulloblastomas in Gorlin syndrome usually have the desmoplastic phenotype, which has been linked, in some studies, with an improved prognosis [47]. If an infratentorial mass is detected during brain MRI, it should be sampled during biopsy as well. The Chang staging system is used to stage medulloblastoma in Gorlin syndrome.

\section{Differential diagnosis}

Precise differential diagnosis needs exclusion of some rare dermatological syndromes, such as Bazex syndrome (characterized by basal-cell carcinoma associated with hypotrichosis, hypohidrosis, milia and folliculare atrophodermia), trichoepithelioma papulosum multiplex (named also epithelioma adenoides cysticum), or Torre's syndrome (Muir-Torre's syndrome).

\section{Genetic counseling}

The syndrome is a hereditary condition, thus referral to a geneticist for counseling is mandatory. NBCC syndrome is caused when one copy of the PTCH1 gene pair contains a fault; this means that every child of a person with the syndrome has a 1 in 2 (50:50) chance of inheriting the faulty gene. The risk to family members is various, about 70$80 \%$ of individuals diagnosed with NBCCS have an affected parent and about $20-30 \%$ of probands have a de novo mutation. The risk to a sib of a proband depends on the genetic status of the parents: if a parent of the proband is affected, the risk to the sibs is $50 \%$; when the parents are clinically unaffected, the risk to the sibs of a proband appears to be low; if the disease-causing mutation cannot 
be detected in the DNA of the parent, the risk to sibs is low, but greater than that of the general population because of the possibility of somatic mosaicism or germline mosaicism exists. The offspring of an individual with mild NBCCS caused by somatic mosaicism may have a risk of less than $50 \%$ of inheriting the disease-causing mutation. The risk to other family members depends upon the genetic status of the proband's parents; if a parent is affected, his or her family members are at risk.

DNA tests, by looking directly at the mutation in the gene, may confirm that the patient is affected by this syndrome. In clinical situations suggesting genetic predisposition to BCC, germline mutations of PTCH1 are not common [107]. Genetic variants might contribute to the variation in numbers of BCCs and jaw cysts observed in NBCCS families [137].

It is recommended to involve families in regular screening. It may be possible to prove whether someone in a family has inherited the condition or not by DNA tests, either by tracking the chromosome 9 containing the faulty gene, or by direct analysis of the mutation causing the disease in a particular family.

In some families, only one person appears to be affected. This event is the result of two conditions: 1 ) the mother or the father have the syndrome, but the effects are so mild that it has never been diagnosed; 2) the fault in the PTCH1 gene has occurred for the first time in that family. It is a "new mutation" [16]. If a family member has not inherited the gene, the surveillance program is not necessary.

The definitive diagnostic test is to demonstrate a mutation in the PTCH1 gene, although this is labor-intensive as there are 24 exons. Recently Fujii et al. used newly designed high-resolution oligonucleotide microarrays with a median distance between the probes of $776 \mathrm{bp}$ (average probe interval 2,271 bp) to detect gene deletions in NBCCS patients. This probe interval was chosen because small submicroscopic genomic deletions and duplications constitute up to $15 \%$ of all mutations underlying human monogenic diseases. Two out of three deletions could not be detected by conventional chromosomal analysis. A submicroscopic deletion as small as $165 \mathrm{~kb}$ was detected affecting only PTCH1, whereas the other two deletions were much larger ( 5 and $11 \mathrm{Mb}$ ) [138].

\section{Antenatal diagnosis}

Antenatal diagnosis may be useful to prevent complications. Ultrasound scans during pregnancy may be helpful in detecting serious developmental malformations, even if they are rare. Some fetuses with NBCCS have large heads and so may need assistance in delivery either by forceps or by Cesarian section. Very rarely, fibroma of the heart may be detected. Prenatal diagnosis for pregnancies at increased risk is possible by analysis of DNA extracted from fetal cells obtained by amniocentesis (usually performed at about 15-18 weeks of gestation) or by chorionic villus sampling (CVS) at about 10-12 weeks of gestation. The disease-causing allele of an affected family member must be identified or linkage established in the family before prenatal testing can be performed. Requests for prenatal testing for conditions such as NBCCS that do not affect intellect, have variable expression and for which some treatments are available, are not common.

\section{Management including treatment}

Patients affected by Gorlin syndrome must be treated by several specialists. Keratocysts can be treated by surgical removal. This requires exposure of the lesion by making an osteotomy in the jawbone under local or general anesthesia, finding the wall of the cyst and removing this completely. Cysts that recur after such a treatment are removed with a bone box including a layer of bone at the margin of the cyst. This is intended to ablate any daughter cysts; only in extreme cases it is necessary to remove an entire section of the affected jawbone.

As regards BCC, only a small fraction of these tumors become invasive and the very rare cases of death result from spread to the brain or lung. Results from several epidemiologic studies have indicated that the risks of BCCs show a strong positive correlation with exposure to UV radiation. Thus, these patients need to avoid excess sun exposure. They must use 100\% UV protective sunglasses as the skin surrounding the eyes (similar to that of the nose/ears) is vulnerable to BCCs. Sunshine during the mid-day hours should be avoided if possible. High factor sunscreens (SPF30+) should be applied before going outside and re-applied every 2-3 hours, or more frequently, if perspiring or swimming.

Radiotherapy should be avoided if possible [6,21]. Tumors on the scalp can be particularly aggressive and need early intervention [5].

Management of superficial BCCs without follicular involvement can be accomplished by total body application of topical $0.1 \%$ tretinoin cream [16]. Patients should be examined every 3 months, and lesions manifesting growth must be excised [16]. More debatable is the use of oral retinoids or combined oral etretinate and surgical treatment [16]. Some authors indicated that doses of 0.5$1.0 \mathrm{mg} / \mathrm{kg} /$ day cause regression of lesions of less than 1.0 $\mathrm{cm}$ and prevent new lesions [139]. Nevertheless, a study of high-dose oral isotretinoin (mean daily dose: $3 \mathrm{mg} / \mathrm{kg} /$ day) found that only $8 \%$ of BCCs underwent complete clinical and histological regression, while all patients 
developed moderate-to-severe acute toxicity [140]. In addition, oral etretinate should not be taken by women of child-bearing age [16], a negative pregnancy test should be obtained prior to therapy and adequate contraception should be used by women during and for at least two months after stopping isotretinoin therapy.

Recent studies indicated that imiquimod 5\% cream appears to be an effective treatment for nodular basal cell carcinoma alone [141-145], or if combined with curettage prior to its application [146]. In fact, 17 nodular BCCs on 15 patients were treated by curettage without electrodesiccation followed by once-daily application of imiquimod $5 \%$ cream, 5 times per week for 6 weeks; the area was excised and examined histologically 6 weeks after cessation of imiquimod cream and all 17 lesions (100\%) showed no histological evidence of residual tumor on the post-treatment excision [146].

Surgical excision is the typical approach for a patient with BCC if the number of lesions is limited. Other treatments that may be effective and more efficient than surgical excision in patients with multiple lesions include laser ablation, photodynamic therapy, and topical chemotherapy [147].

Electrodessication and curettage is a very common procedure used as an alternative to topical chemotherapy in the treatment of small BCCs located in low recurrence areas of the body (neck, trunk, extremities) [148]. The area is first numbed with a local anesthetic injection and then scraped out from surrounding normal skin with a curette. An electrosurgical needle is then used to desiccate (heat and dry up) the remaining cancerous tissue. This is repeated for a total of three or four times in succession in order to achieve maximal cure rates. This form of treatment is quick, efficient and cost effective, but it is of limited value for large lesions and cancers of the mid face due to higher recurrence rates. Pain during treatment is minimal and post-operatively the patient feels nuisance comparable to a small burn. The cosmetic result will appear as a lighter hypopigmented flat spot that is of similar size as the cancer was prior to treatment. The chance of a definitive cure with this procedure is $92-93 \%$. Another possibility is cryosurgery; it is quick, efficient and cost effective. However, this method should be avoided when treating lesions in high recurrence areas. The post-operative cosmetic result, follow-up care, and healing time is very similar to electrodessication and curettage. The overall chance of a cure with this procedure is $92.5 \%$. Cryosurgery, in a few cases, was complicated by nerve damage and numbness, but in general has no side effects, except for scarring. Recently, laser vaporization with the carbon dioxide laser has been used alone or combined with curettage in cases of multiple/superficial tumors [149-151].
Surgical excision by scalpel allows removal of the cancerous tissue plus surrounding normal skin, with minimal discomfort during treatment and in the post-operative period. The cosmetic result is good, but it depends on the size and location of the tumor. The overall chance of a cure with surgical excision may range from $94-98 \%$. Long term side effects include scarring, and rarely, nerve damage. The scalpel excision gives the advantage of being able to check the margins of the specimen microscopically by a pathologist.

Another therapeutic possibility is photodynamic therapy (PDT), a cancer treatment involving use of a photosensitizing dye (given intravenously or topically) that preferentially accumulates within malignant cells [16]. BCCs are then treated with red light (usually produced by a laser) that leads to dye activation and, definitively, to death of these cells [16]. Scabs form over the basal cell carcinomas; the scabs usually fall off by the end of the first month following PDT [16]. The management of patients with NBCCS consists of regular visits (every 2-3 months) to a dermatologist, especially during adolescence [16]. Recently, nodular BCCs resistant to multiple forms of treatment in two patients with NBCCS were treated with systemic porfimer sodium-based photodynamic therapy with a good response to treatment on clinical evaluation and on measurement by a $20-\mathrm{MHz}$ high-resolution ultrasound [152].

Interferon has also been proposed in experimental studies for the treatment of BCCs. This substance is injected directly into the cancer three times each week, for three weeks. Some reports have shown complete resolution of treated tumors, but other studies demonstrated that this treatment was less effective [153]. Side effects include fever, chills, decreased white blood cell count, and pain at the site of injection. This procedure needs to be investigated further.

Patients with Gorlin syndrome can present with medulloblastoma, a malignant tumor of the posterior fossa [52]. Intensive multimodality therapy is typically required to treat medulloblastoma. The best outcomes are obtained in patients who are treated with aggressive resection, chemotherapy, and radiation therapy. Radiotherapy for medulloblastoma causes multiple BCCs in these patients $[154,155]$ or intracranial and sinonasal tumors $[83,156-$ 158 ]; thus, post-operative radiotherapy should be used judiciously. This is particularly important in patients with the desmoplastic NBCCS subtype [47]. As a general rule, if possible, patients should be treated without radiation therapy or using a treatment field that only includes the posterior fossa [159], with a skin-sparing nonconformal technique [159]. In fact, the risk of multiple radiationinduced BCC is decreased with this technique that allows 
the exposition of skin to ionizing radiation to be reduced. On the contrary, this approach may increase the risk of other well-established toxicities, such as ototoxicity and irradiation of the temporal lobes.

\section{Prognosis}

The most common lesions accounting for NBCCS are usually not life-threatening. Medulloblastoma may be a potential cause of early death, even if NBCCS patients may have better outcome than patients with sporadic medulloblastoma (as the desmoplastic subtype of medulloblastoma is associated with an improved survival compared to the classic form of medulloblastoma). Therefore, this could be one argument to limit therapy to young children with Gorlin syndrome and desmoplastic medulloblastoma. Problems can derive from some techniques used for the therapy of specific lesions: i.e. radiation therapy for medulloblastoma that may cause multiple BCCs. For this reason, nonstandard treatments should be considered in children with Gorlin syndrome and medulloblastoma. Chemoprevention may also be used to avoid skin lesions. Vitamin A analogs, such as retinoids, including isotretinoin, may play an important role in preventing or slowing the development of new BCCs [140,160-164].

\section{Support groups}

A list of groups that support patients, families, and clinicians caring for patients with NBCCS is supplied in Additional file 1.

\section{Abbreviations}

NBCCS: Nevoid basal cell carcinoma syndrome; MNBCCS: Multiple nevoid basal-cell carcinoma syndrome; BCNS: Basal cell nevus syndrome; BCCs: Basal cell carcinomas; OKCs: Odontogenic keratocysts; PBCC: Polypoid basal cell carcinomas; RMS: Rhabdomyosarcoma; SHH: Sonic Hedgehog; SNPs: Single nucleotide polymorphisms; MRI: Magnetic resonance imaging; PDT: Photodynamic therapy.

\section{Competing interests}

The author declares that they have no competing interests.

\section{Additional material}

\section{Additional file 1}

A list of groups that support patients, families, and clinicians caring for patients with NBCCS.

Click here for file

[http://www.biomedcentral.com/content/supplementary/17501172-3-32-S1.doc]

\section{References}

I. Gorlin RJ, Goltz RW: Multiple nevoid basal-cell epithelioma, jaw cysts and bifid rib: a syndrome. N Engl J Med 1960, 262:908-912.

2. Jarisch W: Zur Lehre von den Hautgeschwulsten. Arch Dermatol Syphilol 1894, 18: 162-222.

3. White JC: Multiple benign cystic epitheliomas. J Cutan Genitourin Dis 1894, I 2:477-484.

4. Gorlin RJ: Nevoid basal cell carcinoma (Gorlin) syndrome. Genet Med 2004, 6:530-539.

5. Evans DG, Ladusans EJ, Rimmer S, Burnell LD, Thakker N, Farndon PA: Complications of the naevoid basal cell carcinoma syndrome: results of a population based study. J Med Genet 1993, 30:460-464.

6. Kimonis VE, Goldstein AM, Pastakia B, Yang ML, Kase R, DiGiovanna JJ, Bale AE, Bale SJ: Clinical manifestations in 105 persons with nevoid basal cell carcinoma syndrome. Am J Med Genet 1997, 69:299-308.

7. Satinoff MI, Wells C: Multiple basal cell naevus syndrome in ancient Egypt. Med Hist 1969, 13:294-297.

8. Farndon PA, Del Mastro RG, Evans DG, Kilpatrick MW: Location of gene for Gorlin syndrome. Lancet 1992, 339:581-582.

9. Evans DG, Birch JM, Orton Cl: Brain tumours and the occurrence of severe invasive basal cell carcinoma in first degree relatives with Gorlin syndrome. Br J Neurosurg 199|, 5:643-646.

10. Pratt MD, Jackson R: Nevoid basal cell carcinoma syndrome. A I5-year follow-up of cases in Ottawa and the Ottawa Valley. J Am Acad Dermatol 1987, I6:964-970.

II. Lo Muzio L, Nocini PF, Savoia A, Consolo U, Procaccini M, Zelante L, Pannone G, Bucci P, Dolci M, Bambini F, et al:: Nevoid basal cell carcinoma syndrome. Clinical findings in $\mathbf{3 7}$ Italian affected individuals. Clin Genet 1999, 55:34-40.

12. Shanley S, Ratcliffe J, Hockey A, Haan E, Oley C, Ravine D, Martin N, Wicking C, Chenevix-Trench G: Nevoid basal cell carcinoma syndrome: review of 118 affected individuals. Am J Med Genet 1994, 50:282-290.

13. Rahbari $\mathrm{H}$, Mehregan $\mathrm{AH}$ : Basal cell epithelioma (carcinoma) in children and teenagers. Cancer 1982, 49:350-353.

14. Ahn SG, Lim YS, Kim DK, Kim SG, Lee SH, Yoon JH: Nevoid basal cell carcinoma syndrome: a retrospective analysis of 33 affected Korean individuals. Int J Oral Maxillofac Surg 2004, 33:458-462.

15. Pruvost-Balland C, Gorry P, Boutet N, Magnaldo T, Mamelle G, Margulis $A$, Kolb $F$, Duvillard $P$, Spatz $A$, Brugières $L$, Chompret $A$, Avril MF: [Clinical and genetic study in $\mathbf{2 2}$ patients with basal cell nevus syndrome]. Ann Dermatol Venereol 2006, I33: I 17-123.

16. Gorlin RJ: Nevoid basal cell carcinoma syndrome. Dermatol Clin 1995, 13:113-125.

17. Lench NJ, High AS, Markham AF, Hume WJ, Robinson PA: Investigation of chromosome 9q22.3-q3I DNA marker loss in odontogenic keratocysts. Eur J Cancer B Oral Oncol 1996, 32B:202-206.

18. Lo Muzio L, Nocini P, Bucci P, Pannone G, Consolo U, Procaccini M: Early diagnosis of nevoid basal cell carcinoma syndrome. J Am Dent Assoc 1999, 130:669-674.

19. Goldstein AM, Pastakia B, DiGiovanna JJ, Poliak S, Santucci S, Kase R, Bale $A E$, Bale SJ: Clinical findings in two African-American families with the nevoid basal cell carcinoma syndrome (NBCC). Am J Med Genet 1994, 50:272-28I.

20. Giuliani M, Di Stefano L, Zoccali G, Angelone E, Leocata P, Mascaretti G: Gorlin syndrome associated with basal cell carcinoma of the vulva: A case report. Eur J Gynaecol Oncol 2006, 27:519-522.

2I. Gorlin RJ: Nevoid basal-cell carcinoma syndrome. Medicine (Baltimore) 1987, 66:98-II3.

22. Berardi RS, Korba J, Melton J, Chen H: Pulmonary metastasis in nevoid basal cell carcinoma syndrome. Int Surg |99|, 76:64-66.

23. Winkler PA, Guyuron B: Multiple metastases from basal cell naevus syndrome. Br J Plast Surg 1987, 40:528-53I.

24. Wang SQ, Goldberg LH: Multiple polypoid basal cell carcinomas on the perineum of a patient with basal cell nevus syndrome. J Am Acad Dermatol 2007, 57:S36-37.

25. Gutierrez MM, Mora RG: Nevoid basal cell carcinoma syndrome. A review and case report of a patient with unilateral basal cell nevus syndrome. J Am Acad Dermatol 1986, 15:1023-1030. 
26. Friedlander AH, Herbosa EG, Peoples JR 3rd: Ocular hypertelorism, facial basal cell carcinomas, and multiple odontogenic keratocysts of the jaws. J Am Dent Assoc 1988, I | 6:887-889.

27. Wilson LC, Ajayi-Obe E, Bernhard B, Maas SM: Patched mutations and hairy skin patches: a new sign in Gorlin syndrome. $\mathrm{Am} J$ Med Genet A 2006, I 40:2625-2630.

28. Woolgar JA, Rippin JW, Browne RM: The odontogenic keratocyst and its occurrence in the nevoid basal cell carcinoma syndrome. Oral Surg Oral Med Oral Pathol 1987, 64:727-730.

29. Meara JG, Shah S, Li KK, Cunningham MJ: The odontogenic keratocyst: a 20-year clinicopathologic review. Laryngoscope 1998, 108:280-283.

30. Mustaciuolo VW, Brahney CP, Aria AA: Recurrent keratocysts in basal cell nevus syndrome: review of the literature and report of a case. J Oral Maxillofac Surg 1989, 47:870-873.

31. Dominguez FV, Keszler A: Comparative study of keratocysts, associated and non-associated with nevoid basal cell carcinoma syndrome. J Oral Pathol 1988, 17:39-42.

32. Schultz SM, Twickler DM, Wheeler DE, Hogan TD: Ameloblastoma associated with basal cell nevus (Gorlin) syndrome: CT findings. J Comput Assist Tomogr 1987, I I:901-904.

33. Hasegawa K, Amagasa T, Shioda S, Kayano T: Basal cell nevus syndrome with squamous cell carcinoma of the maxilla: report of a case. J Oral Maxillofac Surg 1989, 47:629-633.

34. Ruprecht $\mathrm{A}$, Austermann $\mathrm{KH}$, Umstadt $\mathrm{H}$ : Cleft lip and palate, seldom seen features of the Gorlin-Goltz syndrome. Dentomaxillofac Radiol 1987, 16:99-103.

35. Soekarman D, Fryns JP, Casaer P, Berghe H Van Den: Increased head circumference and facial cleft as presenting signs of the nevoid basal-cell carcinoma syndrome. Genet Couns 1991, 2:157-162

36. Leonardi R, Sorge G, Caltabino M: Bilateral hyperplasia of the mandibular coronoid processes associated with the nevoid basal cell carcinoma syndrome in an Italian boy. $\mathrm{Br}$ Dent J 200I, 190:349-350.

37. Leonardi R, Caltabiano M, Lo Muzio L, Gorlin RJ, Bucci P, Pannone G, Canfora M, Sorge G: Bilateral hyperplasia of the mandibular coronoid processes in patients with nevoid basal cell carcinoma syndrome: an undescribed sign. Am J Med Genet 2002, I 1 0:400-403.

38. Ratcliffe JF, Shanley S, Ferguson J, Chenevix-Trench G: The diagnostic implication of falcine calcification on plain skull radiographs of patients with basal cell naevus syndrome and the incidence of falcine calcification in their relatives and two control groups. BrJ Radiol 1995, 68:36I-368.

39. Takanashi J, Fujii K, Takano H, Sugita K, Kohno Y: Empty sella syndrome in nevoid basal cell carcinoma syndrome. Brain Dev 2000, 22:272-274

40. Lycka BA, Chichak VR: Congenital hydrocephalus and the basal cell nevus syndrome. Can Med Assoc J 1985, I32:1037-1038.

4I. Meyvisch K, Andre J, Song M, Ledoux M: Basal cell nevus syndrome and congenital hydrocephaly. Dermatology 1993, I86:3II-3I2.

42. Murphy MJ, Tenser RB: Nevoid basal cell carcinoma syndrome and epilepsy. Ann Neurol 1982, I I:372-376.

43. Neblett CR, Waltz TA, Anderson DE: Neurological involvement in the nevoid basal cell carcinoma syndrome. J Neurosurg 197|, 35:577-584.

44. Fukushima $Y$, Oka H, Utsuki S, Iwamoto K, Fujii K: Nevoid Basal cell carcinoma syndrome with medulloblastoma and meningioma - case report. Neurol Med Chir (Tokyo) 2004, 44:665-668.

45. Mortimer PS, Geaney DP, Liddell K, Dawber RP: Basal cell naevus syndrome and intracranial meningioma. J Neurol Neurosurg Psychiatry 1984, 47:210-212.

46. Kimonis VE, Mehta SG, Digiovanna JJ, Bale SJ, Pastakia B: Radiological features in 82 patients with nevoid basal cell carcinoma (NBCC or Gorlin) syndrome. Genet Med 2004, 6:495-502.

47. Amlashi SF, Riffaud L, Brassier G, Morandi X: Nevoid basal cell carcinoma syndrome: relation with desmoplastic medulloblastoma in infancy. A population-based study and review of the literature. Cancer 2003, 98:618-624.

48. Atahan IL, Yildiz F, Ozyar E, Uzal D, Zorlu F: Basal cell carcinomas developing in a case of medulloblastoma associated with Gorlin's syndrome. Pediatr Hematol Oncol 1998, I5:|87-191.
49. Cowan R, Hoban P, Kelsey A, Birch JM, Gattamaneni R, Evans DG: The gene for the naevoid basal cell carcinoma syndrome acts as a tumour-suppressor gene in medulloblastoma. $\mathrm{Br} J$ Cancer 1997, 76: $|4|-\mid 45$.

50. Evans DG, Farndon PA, Burnell LD, Gattamaneni HR, Birch JM: The incidence of Gorlin syndrome in 173 consecutive cases of medulloblastoma. Br J Cancer 199I, 64:959-961.

5I. Korczak JF, Brahim JS, DiGiovanna JJ, Kase RG, Wexler LH, Goldstein AM: Nevoid basal cell carcinoma syndrome with medulloblastoma in an African-American boy: a rare case illustrating gene-environment interaction. Am J Med Genet 1997, 69:309-314.

52. Lacombe D, Chateil JF, Fontan D, Battin J: Medulloblastoma in the nevoid basal-cell carcinoma syndrome: case reports and review of the literature. Genet Couns 1990, I:273-277.

53. Romero Perez JA, Lleras Santana I: Basal cell nevus syndrome and medulloblastoma: a case report. Bol Asoc Med P R 1993, 85:24-26.

54. Smucker PS, Smith JL: Multifocal desmoplastic medulloblastoma in an african-american child with nevoid basal cell carcinoma (gorlin) syndrome. Case report. J Neurosurg 2006, 105:315-320

55. Stavrou T, Dubovsky EC, Reaman GH, Goldstein AM, Vezina G: Intracranial calcifications in childhood medulloblastoma: relation to nevoid basal cell carcinoma syndrome. AJNR Am J Neuroradiol 2000, 21 :790-794.

56. Kantarci M, Ertas U, Alper F, Sutbeyaz Y, Karasen RM, Onbas O: Gorlin's syndrome with a thin corpus callosum and a third ventricular cyst. Neuroradiology 2003, 45:390-392.

57. Snider RL: Unusual presentation of a third ventricular cyst in a patient with basal cell nevus syndrome. Pediatr Dermatol I994, I I:323-326.

58. Hogan RE, Tress B, Gonzales MF, King JO, Cook MJ: Epilepsy in the nevoid basal-cell carcinoma syndrome (Gorlin syndrome): report of a case due to a focal neuronal heterotopia. Neurology 1996, 46:574-576.

59. Bale SJ, Amos Cl, Parry DM, Bale AE: Relationship between head circumference and height in normal adults and in the nevoid basal cell carcinoma syndrome and neurofibromatosis type I. Am J Med Genet 199I, 40:206-210.

60. Ratcliffe JF, Shanley S, Chenevix-Trench G: The prevalence of cervical and thoracic congenital skeletal abnormalities in basal cell naevus syndrome; a review of cervical and chest radiographs in 80 patients with BCNS. Br J Radiol 1995, 68:596-599.

6I. Ly JQ: Scintigraphic findings in Gorlin's syndrome. Clin Nucl Med 2002, 27:9|3-9|4.

62. Hawkins JC 3rd, Hoffman HJ, Becker LE: Multiple nevoid basal-cell carcinoma syndrome (Gorlin's syndrome): possible confusion with metastatic medulloblastoma. Case report. J Neurosurg 1979, 50:100-102.

63. Manners RM, Morris RJ, Francis PJ, Hatchwell E: Microphthalmos in association with Gorlin's syndrome. Br J Ophthalmol 1996, 80:378

64. Kraemer BB, Silva EG, Sneige N: Fibrosarcoma of ovary. A new component in the nevoid basal-cell carcinoma syndrome. Am I Surg Pathol 1 984, 8:231-236.

65. Seracchioli R, Colombo FM, Bagnoli A, Trengia V, Venturoli S: Primary ovarian leiomyosarcoma as a new component in the nevoid basal cell carcinoma syndrome: a case report. $\mathrm{Am} J$ Obstet Gynecol 2003, 188:1093-1095.

66. Gorlin RJ, Sedano HO: The multiple nevoid basal cell carcinoma syndrome revisited. Birth Defects Orig Artic Ser I97I, 7:140-I48.

67. Genevieve D, Walter E, Gorry P, Jacquemont ML, Dupic L, Layet V Munnich A, Cormier-Daire V, Dommergues M, Lyonnet S, Mitanchez $D$ : Gorlin syndrome presenting as prenatal chylothorax in a girl. Prenat Diagn 2005, 25:997-999.

68. Case records of the Massachusetts General Hospital. Weekly clinicopathological exercises. Case 10-1986. A 65year-old woman with abdominal masses and a history of multiple basal-cell carcinomas. N Engl J Med I 986, 3 I 4:700-706.

69. Bossert T, Walther T, Vondrys D, Gummert JF, Kostelka M, Mohr FW: Cardiac fibroma as an inherited manifestation of nevoid basal-cell carcinoma syndrome. Tex Heart Inst J 2006, 33:88-90.

70. Coffin CM: Congenital cardiac fibroma associated with Gorlin syndrome. Pediatr Pathol 1992, I 2:255-262. 
7I. Herman TE, Siegel MJ, McAlister WH: Cardiac tumor in Gorlin syndrome. Nevoid basal cell carcinoma syndrome. Pediatr Radiol I 991, 2 I:234-235.

72. Pauliks LB, Miller S, Banerjee A: Intracardiac fibroma in nevoidbasal cell carcinoma (gorlin) syndrome: tissue characterization by strain rate imaging. Echocardiography 2006, 23:79-80.

73. Reiter C, Hiss ], Muller-Hartburg W: [Cardiac fibroma in familial Gorlin syndrome with virilism]. Wien Klin Wochenschr 1982, 94:430-434.

74. Santava A, Michalkova K, Brazda A, Vacha P: [The basal cell nevus syndrome. Case report of a I4-year-old girl]. Cesk Pediatr 1993, 48: $129-132$

75. Hogge WA, Blank C, Roochvarg LB, Hogge JS, Wulfsberg EA, Raffel LJ: Gorlin syndrome (naevoid basal cell carcinoma syndrome): prenatal detection in a fetus with macrocephaly and ventriculomegaly. Prenat Diagn 1994, I4:725-727.

76. Beddis IR, Mott MG, Bullimore J: Case report: nasopharyngeal rhabdomyosarcoma and Gorlin's naevoid basal cell carcinoma syndrome. Med Pediatr Oncol I983, I I:I78-I79.

77. Cajaiba MM, Bale AE, Alvarez-Franco M, McNamara J, Reyes-Mugica $M$ : Rhabdomyosarcoma, Wilms tumor, and deletion of the patched gene in Gorlin syndrome. Nat Clin Pract Oncol 2006 , 3:575-580.

78. Watson J, Depasquale K, Ghaderi M, Zwillenberg S: Nevoid basal cell carcinoma syndrome and fetal rhabdomyoma: a case study. Ear Nose Throat J 2004, 83:7 I6-7/8.

79. Calzada-Wack J, Schnitzbauer U, Walch A, Wurster KH, Kappler R, Nathrath M, Hahn $\mathrm{H}$ : Analysis of the PTCH coding region in human rhabdomyosarcoma. Hum Mutat 2002, 20:233-234.

80. Herzberg JJ, Wiskemann A: Die fünfte Phakomatose. Basalzellnaevus mit familiärer Belastung und Medulloblastom. [The fifth phakomatosis. Basal cell nevus with hereditary malformation and medulloblastoma.]. Dermatologica 1963, 126:106-123.

8I. Schofield D, West DC, Anthony DC, Marshal R, Sklar J: Correlation of loss of heterozygosity at chromosome $9 q$ with histological subtype in medulloblastomas. Am J Pathol 1995, I 46:472-480.

82. Su CW, Lin KL, Hou JW, Jung SM, Zen EC: Spontaneous recovery from a medulloblastoma by a female with Gorlin-Goltz syndrome. Pediatr Neurol 2003, 28:231-234.

83. O'Malley S, Weitman D, Olding M, Sekhar L: Multiple neoplasms following craniospinal irradiation for medulloblastoma in a patient with nevoid basal cell carcinoma syndrome. Case report. J Neurosurg 1997, 86:286-288.

84. Schweisguth $O$, Gerard-Marchant $R$, Lemerle J: Naevomatose basocellulaire; association a' un rhabdomyosarcome congenital. [Basal cell nevus syndrome. Association with congenital rhabdomyosarcoma]. Arch Fr Pediatr 1968, 25:1083-1093.

85. Dahl I, Angervall L, Save-Soderbergh J: Foetal rhabdomyoma. Case report of a patient with two tumours. Acta Pathol Microbiol Scand [A] 1976, 84: 107-II2.

86. DiSanto $S, A b t A B$, Boal DK, Krummel TM: Fetal rhabdomyoma and nevoid basal cell carcinoma syndrome. Pediatr Pathol 1992, I 2:44|-447.

87. Hardisson D, Jimenez-Heffernan JA, Nistal M, Picazo ML, Tovar JA, Contreras F: Neural variant of fetal rhabdomyoma and naevoid basal cell carcinoma syndrome. Histopathology 1996, 29:247-252.

88. Klijanienko J, Caillaud JM, Micheau C, Flamant F, Schwaab G, Avril MF, Ponzio-Prion A: [Basal-cell nevomatosis associated with multifocal fetal rhabdomyoma. A case]. Presse Med 1988, I 7:2247-2250

89. Tostar U, Malm CJ, Meis-Kindblom JM, Kindblom LG, Toftgard R, Unden $A B$ : Deregulation of the hedgehog signalling pathway: a possible role for the PTCH and SUFU genes in human rhabdomyoma and rhabdomyosarcoma development. J Pathol 2006, 208: 17-25.

90. Schulz-Butulis BA, Gilson R, Farley M, Keeling JH: Nevoid basal cell carcinoma syndrome and non-Hodgkin's lymphoma. Cutis 2000, 66:35-38

91. Yilmaz B, Goldberg LH, Schechter NR, Kemp BL, Ruiz H: Basal cell nevus syndrome concurrent with adenoid cystic carcinoma of salivary gland. J Am Acad Dermatol 2003, 48:S64-66.

92. Zaun $\mathrm{H}$ : [Basal cell nevus syndrome with unusual accompanying symptoms]. Hautarzt 1981, 32:455-458.
93. Bare JW, Lebo RV, Epstein EH Jr: Loss of heterozygosity at chromosome Iq22 in basal cell carcinomas and exclusion of the basal cell nevus syndrome gene from this site. Cancer Res 1992, 52:1494-|498.

94. Bialer MG, Gailani MR, McLaughlin JA, Petrikovsky B, Bale AE: Prenatal diagnosis of Gorlin syndrome. Lancet 1994, 344:477.

95. Bonifas JM, Bare JW, Kerschmann RL, Master SP, Epstein EH Jr: Parental origin of chromosome 9q22.3-q3 I lost in basal cell carcinomas from basal cell nevus syndrome patients. Hum Mol Genet 1994, 3:447-448.

96. Gailani MR, Bale SJ, Leffell DJ, DiGiovanna JJ, Peck GL, Poliak S, Drum MA, Pastakia B, McBride OW, Kase R, et al.: Developmental defects in Gorlin syndrome related to a putative tumor suppressor gene on chromosome 9. Cell 1992, 69: III-II7.

97. Chenevix-Trench G, Wicking C, Berkman J, Sharpe H, Hockey A Haan E, Oley C, Ravine D, Turner A, Goldgar D, et al.: Further localization of the gene for nevoid basal cell carcinoma syndrome (NBCCS) in I 5 Australasian families: linkage and loss of heterozygosity. Am J Hum Genet 1993, 53:760-767.

98. Levanat S, Gorlin RJ, Fallet S, Johnson DR, Fantasia JE, Bale AE: A two-hit model for developmental defects in Gorlin syndrome. Nat Genet 1996, I 2:85-87.

99. Levanat S, Pavelic B, Crnic I, Oreskovic S, Manojlovic S: Involvement of PTCH gene in various noninflammatory cysts. J Mol Med 2000, 78: $140-146$.

100. Wicking C, Bale AE: Molecular basis of the nevoid basal cell carcinoma syndrome. Curr Opin Pediatr 1997, 9:630-635.

I0I. Hahn H, Wicking C, Zaphiropoulous PG, Gailani MR, Shanley S, Chidambaram A, Vorechovsky I, Holmberg E, Unden AB, Gillies S, et al: Mutations of the human homolog of Drosophila patched in the nevoid basal cell carcinoma syndrome. Cell 1996, 85:84|-85I.

102. Johnson RL, Rothman AL, Xie J, Goodrich LV, Bare JW, Bonifas JM, Quinn AG, Myers RM, Cox DR, Epstein EH Jr, Scott MP: Human homolog of patched, a candidate gene for the basal cell nevus syndrome. Science 1996, 272:1668-167I.

103. Wicking C, Gillies S, Smyth I, Shanley S, Fowles L, Ratcliffe J, Wainwright B, Chenevix-Trench G: De novo mutations of the Patched gene in nevoid basal cell carcinoma syndrome help to define the clinical phenotype. Am J Med Genet 1997, 73:304-307.

104. Pastorino L, Cusano R, Nasti S, Faravelli F, Forzano F, Baldo C, Barile M, Gliori S, Muggianu M, Ghigliotti G, et al: Molecular characterization of Italian nevoid basal cell carcinoma syndrome patients. Hum Mutat 2005, 25:322-323.

105. Savino M, d'Apolito M, Formica V, Baorda F, Mari F, Renieri A, Carabba E, Tarantino E, Andreucci E, Belli S, et al.: Spectrum of PTCH mutations in Italian nevoid basal cell-carcinoma syndrome patients: identification of thirteen novel alleles. Hum Mutat 2004, 24:44I

106. Lee YW, Roh BH, Ki CS, Park YL, Shin HB, Lee YK, Choi TY, Whang $\mathrm{KU}$ : Identification of a novel mutation in the $\mathrm{PTCH}$ gene in a Korean family with naevoid basal cell carcinoma syndrome. Clin Exp Dermatol 2007, 32:202-203.

107. Soufir N, Gerard B, Portela M, Brice A, Liboutet M, Saiag P, Descamps V, Kerob D, Wolkenstein P, Gorin I, et al:: PTCH mutations and deletions in patients with typical nevoid basal cell carcinoma syndrome and in patients with a suspected genetic predisposition to basal cell carcinoma: a French study. Br J Cancer 2006, 95:548-553.

108. Song YL, Zhang WF, Peng B, Wang CN, Wang Q, Bian Z: Germline mutations of the PTCH gene in families with odontogenic keratocysts and nevoid basal cell carcinoma syndrome. Tumour Biol 2006, 27: 175-180.

109. Matsuzawa N, Nagao T, Shimozato K, Niikawa N, Yoshiura KI: Patched homologue I mutations in four Japanese families with basal cell nevus syndrome. J Clin Pathol 2006, 59: I 084-1086.

I 10. Lindstrom E, Shimokawa T, Toftgard R, Zaphiropoulos PG: PTCH mutations: distribution and analyses. Hum Mutat 2006, 27:215-219.

I I I. Tanioka M, Takahashi K, Kawabata T, Kosugi S, Murakami K, Miyachi Y, Nishigori C, lizuka T: Germline mutations of the PTCH gene in Japanese patients with nevoid basal cell carcinoma syndrome. Arch Dermatol Res 2005, 296:303-308.

II2. Boonen SE, Stahl D, Kreiborg S, Rosenberg T, Kalscheuer V, Larsen LA, Tommerup N, Brondum-Nielsen K, Tumer Z: Delineation of 
an interstitial 9q22 deletion in basal cell nevus syndrome. Am J Med Genet A 2005, I32A(3):324-328.

I I3. Boonen SE, Stahl D, Kreiborg S, Rosenberg T, Kalscheuer V, Larsen LA, Tommerup N, Brondum-Nielsen K, Tumer Z: Delineation of an interstitial 9q22 deletion in basal cell nevus syndrome. $A m$ J Med Genet A 2004, I 32A(3):324-328.

I 14. Haniffa MA, Leech SN, Lynch SA, Simpson NB: NBCCS secondary to an interstitial chromosome 9q deletion. Clin Exp Dermatol 2004, 29:542-544.

I I5. Boutet N, Bignon Y], Drouin-Garraud V, Sarda P, Longy M, Lacombe $D$, Gorry P: Spectrum of PTCHI mutations in French patients with Gorlin syndrome. J Invest Dermatol 2003, I 2 1:478-48I.

1 16. Tate G, Li M, Suzuki T, Mitsuya T: A new germline mutation of the PTCH gene in a Japanese patient with nevoid basal cell carcinoma syndrome associated with meningioma. Jpn J Clin Oncol 2003, 33:47-50.

1 17. Lam CW, Leung CY, Lee KC, Xie J, Lo FM, Au TS, Tong SF, Poon MK, Chan LY, Luk NM: Novel mutations in the PATCHED gene in basal cell nevus syndrome. Mol Genet Metab 2002, 76:57-6I.

I 18. Minami M, Urano Y, Ishigami T, Tsuda H, Kusaka J, Arase S: Germline mutations of the PTCH gene in Japanese patients with nevoid basal cell carcinoma syndrome. J Dermatol Sci 200I, 27:2I-26.

119. Gailani MR, Stahle-Backdahl M, Leffell DJ, Glynn M, Zaphiropoulos PG, Pressman C, Unden AB, Dean M, Brash DE, Bale AE, Toftgard R: The role of the human homologue of Drosophila patched in sporadic basal cell carcinomas. Nat Genet 1996, 14:78-8I.

120. Raffel C, Jenkins RB, Frederick L, Hebrink D, Alderete B, Fults DW, James CD: Sporadic medulloblastomas contain PTCH mutations. Cancer Res 1997, 57:842-845.

121. Stone DM, Hynes M, Armanini M, Swanson TA, Gu Q, Johnson RL, Scott MP, Pennica D, Goddard A, Phillips H, et al:: The tumour-suppressor gene patched encodes a candidate receptor for Sonic hedgehog. Nature 1996, 384:129-134.

122. Sidransky D: Is human patched the gatekeeper of common skin cancers? Nat Genet 1996, 14:7-8.

123. Barreto DC, Gomez RS, Bale AE, Boson WL, De Marco L: PTCH gene mutations in odontogenic keratocysts. J Dent Res 2000, 79:1418-1422

124. Shear $\mathrm{M}$ : The aggressive nature of the odontogenic keratocyst: is it a benign cystic neoplasm? Part 2. Proliferation and genetic studies. Oral Oncol 2002, 38:323-33I.

125. Matsumura Y, Nishigori C, Murakami K, Miyachi Y: Allelic loss at the PTCH gene locus in jaw cysts but not in palmar pits in patients with basal cell nevus syndrome. Arch Dermatol Res 2000, 292:475-476.

126. Agaram NP, Collins BM, Barnes L, Lomago D, Aldeeb D, Swalsky P, Finkelstein S, Hunt JL: Molecular analysis to demonstrate that odontogenic keratocysts are neoplastic. Arch Pathol Lab Med 2004, I 28:3 |3-3 I7.

127. Wicking C, Berkman J, Wainwright B, Chenevix-Trench G: Fine genetic mapping of the gene for nevoid basal cell carcinoma syndrome. Genomics 1994, 22:505-5II.

128. Xie J, Johnson RL, Zhang X, Bare JW, Waldman FM, Cogen PH, Menon AG, Warren RS, Chen LC, Scott MP, Epstein EH Jr: Mutations of the PATCHED gene in several types of sporadic extracutaneous tumors. Cancer Res 1997, 57:2369-2372.

129. Richards FM, Goudie DR, Cooper WN, Jene Q, Barroso I, Wicking C, Wainwright BJ, Ferguson-Smith MA: Mapping the multiple selfhealing squamous epithelioma (MSSE) gene and investigation of xeroderma pigmentosum group $A$ (XPA) and PATCHED (PTCH) as candidate genes. Hum Genet 1997, 101:317-322.

130. Gu XM, Zhao HS, Sun LS, Li TJ: PTCH mutations in sporadic and Gorlin-syndrome-related odontogenic keratocysts. J Dent Res 2006, 85:859-863.

131. Fujii K, Kohno Y, Sugita K, Nakamura M, Moroi Y, Urabe K, Furue M, Yamada M, Miyashita T: Mutations in the human homologue of Drosophila patched in Japanese nevoid basal cell carcinoma syndrome patients. Hum Mutat 2003, 2 I:45I-452.

132. Strange RC, El-Genidy N, Ramachandran S, Lovatt TJ, Fryer AA, Smith AG, Lear JT, Wong C, Jones PW, Ichii-Jones F, Hoban PR: Susceptibility to basal cell carcinoma: associations with PTCH polymorphisms. Ann Hum Genet 2004, 68:536-545.
133. Klein RD, Dykas DJ, Bale AE: Clinical testing for the nevoid basal cell carcinoma syndrome in a DNA diagnostic laboratory. Genet Med 2005, 7:6I I-619.

134. Smyth I, Narang MA, Evans T, Heimann C, Nakamura Y, ChenevixTrench G, Pietsch T, Wicking C, Wainwright BJ: Isolation and characterization of human patched 2 ( $\mathrm{PTCH} 2)$, a putative tumour suppressor gene inbasal cell carcinoma and medulloblastoma on chromosome Ip32. Hum Mol Genet 1999, 8:29|-297.

135. Lee Y, Miller HL, Russell HR, Boyd K, Curran T, McKinnon PJ: Patched2 modulates tumorigenesis in patchedI heterozygous mice. Cancer Res 2006, 66:6964-697I.

136. Littler BO: Gorlin's syndrome and the heart. Br J Oral Surg 1979, I7:135-146.

137. X RY, Pfeiffer RM, Goldstein AM: Influence of glutathione-Stransferase (GSTMI, GSTPI, GSTTI) and cytochrome p450 (CYPIAI, CYP2D6) polymorphisms on numbers of basal cell carcinomas (BCCs) in families with the naevoid basal cell carcinoma syndrome. J Med Genet 2006, 43:el6.

138. Fujii K, Ishikawa $S$, Uchikawa $H$, Komura $D$, Shapero $M H$, Shen $F$, Hung J, Arai H, Tanaka Y, Sasaki K, et al:: High-density oligonucleotide array with sub-kilobase resolution reveals breakpoint information of submicroscopic deletions in nevoid basal cell carcinoma syndrome. Hum Genet 2007, 122:459-466.

139. Sanchez-Conejo-Mir J, Camacho F: Nevoid basal cell carcinoma syndrome: combined etretinate and surgical treatment. J Dermatol Surg Oncol 1989, 15:868-87I.

140. Peck GL, DiGiovanna JJ, Sarnoff DS, Gross EG, Butkus D, Olsen TG, Yoder FW: Treatment and prevention of basal cell carcinoma with oral isotretinoin. J Am Acad Dermatol 1988, 19:176-185.

14I. Ferreres JR, Macaya A, Jucgla A, Muniesa C, Prats C, Peyri J: Hundreds of basal cell carcinomas in a Gorlin-Goltz syndrome patient cured with imiquimod $5 \%$ cream. J Eur Acad Dermatol Venereol 2006, 20:877-878.

142. Vereecken P, Monsieur E, Petein M, Heenen M: Topical application of imiquimod for the treatment of high-risk facial basal cell carcinoma in Gorlin syndrome. J Dermatolog Treat 2004, 15:|20- $|2|$

143. Micali G, De Pasquale R, Caltabiano R, Impallomeni R, Lacarrubba F: Topical imiquimod treatment of superficial and nodular basal cell carcinomas in patients affected by basal cell nevus syndrome: a preliminary report. J Dermatolog Treat 2002, 13:123-127.

144. Micali G, Lacarrubba F, Nasca MR, De Pasquale R: The use of imiquimod $5 \%$ cream for the treatment of basal cell carcinoma as observed in Gorlin's syndrome. Clin Exp Dermatol 2003, 28(Suppl I): 19-23.

145. Stockfleth E, Ulrich C, Hauschild A, Lischner S, Meyer T, Christophers E: Successful treatment of basal cell carcinomas in a nevoid basal cell carcinoma syndrome with topical $5 \%$ imiquimod. Eur J Dermatol 2002, 1 2:569-572.

146. Neville JA, Williford PM, Jorizzo JL: Pilot study using topical imiquimod $5 \%$ cream in the treatment of nodular basal cell carcinoma after initial treatment with curettage. J Drugs Dermatol 2007, 6:910-914.

147. Oseroff AR, Blumenson LR, Wilson BD, Mang TS, Bellnier DA, Parsons JC, Frawley N, Cooper M, Zeitouni N, Dougherty TJ: A dose ranging study of photodynamic therapy with porfimer sodium (Photofrin) for treatment of basal cell carcinoma. Lasers Surg Med 2006, 38:4I7-426.

148. Southwick G], Schwartz RA: The basal cell nevus syndrome: disasters occurring among a series of 36 patients. Cancer 1979, 44:2294-2305.

149. Doctoroff A, Oberlender SA, Purcell SM: Full-face carbon dioxide laser resurfacing in the management of a patient with the nevoid basal cell carcinoma syndrome. Dermatol Surg 2003, 29: $1236-1240$

150. Grobbelaar AO, Horlock N, Gault DT: Gorlin's syndrome: the role of the carbon dioxide laser in patient management. Ann Plast Surg 1997, 39:366-373.

15I. Nouri K, Chang A, Trent JT, Jimenez GP: Ultrapulse CO2 used for the successful treatment of basal cell carcinomas found in patients with basal cell nevus syndrome. Dermatol Surg 2002, 28:287-290.

152. Madan V, Loncaster JA, Allan D, Lear JT, Sheridan L, Leach C, Allan E: Nodular basal cell carcinoma in Gorlin's syndrome treated 
with systemic photodynamic therapy and interstitial optical fiber diffuser laser. J Am Acad Dermatol 2006, 55:S86-89.

153. Sollitto RB, DiGiovanna JJ: Failure of interferon alfa and isotretinoin combination therapy in the nevoid basal cell carcinoma syndrome. Arch Dermatol 1996, 132:94-95.

154. Marin-Gutzke M, Sanchez-Olaso A, Berenguer B, Gonzalez B, Rodriguez $\mathrm{P}$, De Salamanca JE, De Prada I: Basal cell carcinoma in childhood after radiation therapy: case report and review. Ann Plast Surg 2004, 53:593-595.

155. Mancuso M, Pazzaglia S, Tanori M, Hahn H, Merola P, Rebessi S, Atkinson MJ, Di Majo V, Covelli V, Saran A: Basal cell carcinoma and its development: insights from radiation-induced tumors in Ptch I-deficient mice. Cancer Res 2004, 64:934-94I.

156. Choudry Q, Patel HC, Gurusinghe NT, Evans DG: Radiationinduced brain tumours in nevoid basal cell carcinoma syndrome: implications for treatment and surveillance. Childs Nerv Syst 2007, 23:133-136.

157. Wallin JL, Tanna N, Misra S, Puri PK, Sadeghi N: Sinonasal carcinoma after irradiation for medulloblastoma in nevoid basal cell carcinoma syndrome. Am J Otolaryngol 2007, 28:360-362.

158. Campbell RM, Mader RD, Dufresne RG Jr: Meningiomas after medulloblastoma irradiation treatment in a patient with basal cell nevus syndrome. I Am Acad Dermatol 2005, 53:S256-259.

159. Walter AW: Gorlin Syndrome. emedicine 2006.

160. Campbell RM, DiGiovanna J]: Skin cancer chemoprevention with systemic retinoids: an adjunct in the management of selected high-risk patients. Dermatol Ther 2006, 19:306-314.

161. DiGiovanna JJ: Retinoid chemoprevention in the high-risk patient. J Am Acad Dermatol 1998, 39:S82-85.

162. Goldberg LH, Hsu SH, Alcalay J: Effectiveness of isotretinoin in preventing the appearance of basal cell carcinomas in basal cell nevus syndrome. J Am Acad Dermatol 1989, 21:144-145.

163. Peck GL: Long-term retinoid therapy is needed for maintenance of cancer chemopreventive effect. Dermatologica 1987, I 75(Suppl I): I38-| 44 .

164. Peck GL, Gross EG, Butkus D, DiGiovanna J]: Chemoprevention of basal cell carcinoma with isotretinoin. J Am Acad Dermatol 1982, 6:815-823

Publish with Bio Med Central and every scientist can read your work free of charge

"BioMed Central will be the most significant development for disseminating the results of biomedical research in our lifetime. "

Sir Paul Nurse, Cancer Research UK

Your research papers will be:

- available free of charge to the entire biomedical community

- peer reviewed and published immediately upon acceptance

- cited in PubMed and archived on PubMed Central

- yours - you keep the copyright
BioMedcentral 